\title{
Reproductive Performance of Dairy Cows Fed Two Concentrations of Phosphorus*
}

\author{
H. Lopez, ${ }^{1}$ F. D. Kanitz, ${ }^{2}$ V. R. Moreira, ${ }^{1}$ L. D. Satter, ${ }^{1,2}$ and M. C. Wiltbank ${ }^{1}$ \\ ${ }^{1}$ Department of Dairy Science, University of Wisconsin, \\ ${ }^{2} U$.S. Dairy Forage Research Center, \\ USDA-Agricultural Research Service, \\ Madison 53706
}

\begin{abstract}
The objective of this study was to determine the effect of dietary $\mathrm{P}$ concentrations of 0.37 (recommended) or $0.57 \%$ (excess; dry matter basis) on reproductive performance. At calving, Holstein cows were randomly assigned to 1 of 2 dietary treatments $(\mathrm{n}=$ 134 for $0.37 \% \mathrm{P}$ and $\mathrm{n}=133$ for $0.57 \% \mathrm{P}$ ). Cows were fitted with a radiotelemetric transmitter $(50 \mathrm{~d}$ in milk [DIM] ) to record mounting activity during estrus and bred to natural estrus from 50 to 100 DIM, then to synchronized estrus (Ovsynch protocol) after 100 DIM. Weekly ultrasonography was performed from 50 DIM until pregnancy was diagnosed ( $30 \mathrm{~d}$ after artificial insemination). Pregnancy was confirmed approximately $60 \mathrm{~d}$ after artificial insemination (artificial insemination). Weekly blood samples were analyzed for progesterone concentrations. Days to first increase ( $>1$ $\mathrm{ng} / \mathrm{ml}$ ) in progesterone, days to first estrus detected by radiotelemetry, days to first service detected by herd personnel, and conception rate at first service did not differ between the recommended and excess $\mathrm{P}$ groups, respectively. Similarly, conception rate at $30 \mathrm{~d}$, days open, pregnancies lost from 30 to $60 \mathrm{~d}$, multiple ovulation rate, and the incidence of anovulatory condition at 71 DIM did not differ between these groups. The mean duration of estrus was $8.7 \pm 0.5$ and $8.7 \pm 0.7 \mathrm{~h}$, and the average number of mounts per estrus was $7.4 \pm 0.5$ and $7.8 \pm 0.5$ for a total mounting time during estrus of $25.8 \pm 1.8$ and $24.5 \pm 1.6 \mathrm{~s}$ for cows fed the recommended and excess $\mathrm{P}$ diet, respectively. Phosphorus treatment had no detectable effect on reproductive performance.
\end{abstract}

\footnotetext{
Received April 3, 2003.

Accepted August 7, 2003.

Corresponding author: M. C. Wiltbank; e-mail: wiltbank@calshp. cals.wisc.edu.

*Trade names and the names of commercial companies are used in this report to provide specific information. Mention of a trade name or manufacturer does not constitute a guarantee or warranty of the product by the USDA or an endorsement over products not mentioned.
}

(Key words: dairy cow, reproductive performance, phosphorus requirement)

Abbreviation key: $\mathbf{C L}=$ corpus luteum, $\mathbf{P}_{\mathbf{4}}=$ progesterone.

\section{INTRODUCTION}

There is a widely held view relating poor reproductive performance in cattle to reduced $\mathrm{P}$ intake. Published reports from 1932 through 2000 have analyzed this relationship and have obtained varying results. Early research reported poor reproductive efficiency in range cattle maintained in areas of $\mathrm{P}$ deficient pastures (Theiler et al., 1928; Eckles et al., 1932). In these early reports, decreased calf crops and extended periods of anestrus were often accompanied by clinical symptoms of P deficiency (i.e., osteoporosis, osteomalacia, osteophagia, cachexia, anorexia) probably reflecting the extremely low concentrations of dietary P. In addition, a combination of dietary deficiencies, rather than an exclusive $\mathrm{P}$ deficiency, may have had an adverse effect on the reproductive performance of the cattle maintained on $\mathrm{P}$ deficient pastures (Palmer et al., 1941). Even though the early studies relating poor reproductive performance to low $\mathrm{P}$ intake were a compilation of field observations from areas of naturally occurring $\mathrm{P}$ deficiency, and where $\mathrm{P}$ was probably not the only limiting factor, they initially established the concept relating low $\mathrm{P}$ intake to poor reproductive performance.

Later research has analyzed the relationship between dietary $\mathrm{P}$, milk production, and reproductive performance of lactating cattle (Wu et al., 2000, 2001; Wu and Satter, 2000). Wu et al. (2001) established that dietary $\mathrm{P}$ of $0.31 \%$ was marginally deficient for high producing $(>11,900 \mathrm{~kg} / 308 \mathrm{~d})$ cows, based on the observation of decreased $\mathrm{P}$ content in bone at the end of 2 lactations. In general, results for the studies analyzing dietary $\mathrm{P}$ and milk production suggest that dietary $\mathrm{P}$ concentrations between 0.31 and $0.38 \%$ might be recommended for moderate- to high-producing cows. 
The relationship between dietary $\mathrm{P}$ and reproductive performance has also been analyzed. Wu and Satter (2000) summarized 8 studies relating dietary $P$ to reproduction of dairy cows. They found that reproductive performance of cows fed low $\mathrm{P}$ diets $(0.31$ to $0.40 \%)$ was similar to cows fed high P diets (0.39 to $0.55 \%)$. Although the number of animals in these studies was not sufficient to draw definitive conclusions on reproductive measurements (Wu and Satter, 2000), the results suggest that reproductive performance is not compromised when the diet contains a minimum of 0.31 to $0.39 \%$ of $\mathrm{P}$.

Although dietary $\mathrm{P}$ concentrations have been reduced somewhat during the last 2 to $3 \mathrm{yr}$, most dairy diets still contain $\mathrm{P}$ concentrations 15 to $20 \%$ in excess of the National Research Council (NRC, 2001) requirements, due in part to the perception that high $\mathrm{P}$ intake improves reproductive efficiency. The current NRC requirements for early to midlactation (90 DIM) diets are $0.36 \% \mathrm{P}$ (DM basis) for cows milking $45 \mathrm{~kg} / \mathrm{d}$ and $0.35 \% \mathrm{P}$ for cows milking $35 \mathrm{~kg} / \mathrm{d}$. Supplemental P is normally fed to obtain the high concentrations of dietary P currently fed by producers since unsupplemented dairy diets usually contain between 0.33 to $0.40 \% \mathrm{P}$ (Wu et al., 2000).

Although a reduction in $\mathrm{P}$ supplementation of dairy diets is environmentally and economically sound, data are needed to clarify the relationship between dietary $\mathrm{P}$ and reproductive efficiency of the herd (Wu and Satter, 2000). Therefore, this experiment was designed to compare reproductive measurements for dairy cows fed a diet close to the NRC requirement $(0.37 \% \mathrm{P}=$ recommended), or a diet in excess of the NRC requirement $(0.57 \% \mathrm{P}=$ excess $)$. The general hypothesis for this study was that cows fed a diet containing an excess concentration of $\mathrm{P}$ would have improved reproductive performance compared with cows fed a diet containing a recommended $\mathrm{P}$ concentration.

\section{MATERIALS AND METHODS}

\section{Animals, Diets, and Procedures}

This study used 267 (131 primiparous and 136 multiparous) Holstein cows that were fed 1 of 2 diets differing only in $\mathrm{P}$ content. A recommended $\mathrm{P} \operatorname{diet}(0.37 \%$ $\mathrm{P}-\mathrm{DM}$ basis) containing no supplemental $\mathrm{P}$ and an excess $\mathrm{P}$ diet $(0.57 \% \mathrm{P}-\mathrm{DM}$ basis) that was obtained by the addition of monosodium phosphate $\left(\mathrm{NaH}_{2} \mathrm{PO}_{4}\right)$ to the TMR. At calving, every cow was randomly assigned to 1 of the 2 dietary $\mathrm{P}$ treatments $(\mathrm{n}=134$ for $0.37 \% \mathrm{P}$ and $\mathrm{n}=133$ for $0.57 \% \mathrm{P}$ ). During the first 3 wk of lactation, cows were housed in a tie-stall barn and individually fed the corresponding recommended or excess $\mathrm{P}$ transition diets ad libitum. Cows were moved to a free-stall barn with concrete flooring after wk 3 where they remained until the end of the trial. The corresponding recommended or excess $\mathrm{P}$ diets were offered once daily ad libitum. Diet ingredients were analyzed for DM, CP, NDF, ADF, and P content (Lopez et al., 2003).

Blood samples $(\sim 10 \mathrm{ml})$ were collected via coccygeal venipuncture on approximately 50 and 100 DIM. Samples were centrifuged at $1600 \times g$ for $15 \mathrm{~min}$, and serum was analyzed for inorganic $\mathrm{P}$ concentrations by the Marshfield Laboratories (Marshfield, WI) using the molybdovanadate colorimetric procedure (AOAC, 1980). Information on the diets, methods, and procedures as well as results of milk yield, milk composition, serum $\mathrm{P}$ concentrations, body condition, and health status for cows fed the recommended and excess $\mathrm{P}$ diets are reported in an accompanying paper (Lopez et al., 2004). The protocol used in this experiment was approved by the Animal Care Committee of the College of Agricultural and Life Sciences, University of Wisconsin, Madison.

\section{Characterization of Estrous Behavior}

To accurately characterize the length and intensity of behavioral estrus it is essential that cows be continuously monitored. To accomplish this, all cows were fitted at the end of the voluntary waiting period (50 DIM) with a radiotelemetric transmitter (HeatWatch; DDx, Denver, CO) that allowed $24 \mathrm{~h} / \mathrm{d}$ recording of mounting activity. The HeatWatch system included pressure-sensitive transmitters with a $0.4-\mathrm{km}$ range signal transmission, a signal receiver unit with a 1200-m radius signal detection that was located approximately $100 \mathrm{~m}$ from the free-stall barn where cows were housed, a buffer for receiving and storing activity data sent by the receiver, and PC-compatible software for interpreting the information. All areas of cow traffic were within the detection range of the transmitter signal. Transmitters were powered by a lithium $3-\mathrm{V}$ battery and secured in $10-\times 5$-cm polyester pouches that were attached to $25-\times 20-\mathrm{cm}$ patches. Patches were glued to the tailhead of the cow, and an attached strap was secured to the tail. Activation of a transmitter by the weight of a mounting cow for a minimum of $2 \mathrm{~s}$ interrupts a radio-wave transmission generating real time data. The transmitted data (date, time, duration, cow number, and transmitter number) were recorded by the software using a mount data log. Onset of estrus was identified by the first activation of the transmitter. Duration of estrus was defined as the time interval from the first to last mount recorded during estrus, thus excluding an estrus consisting of only one mount for this measure. Ovulation was con- 


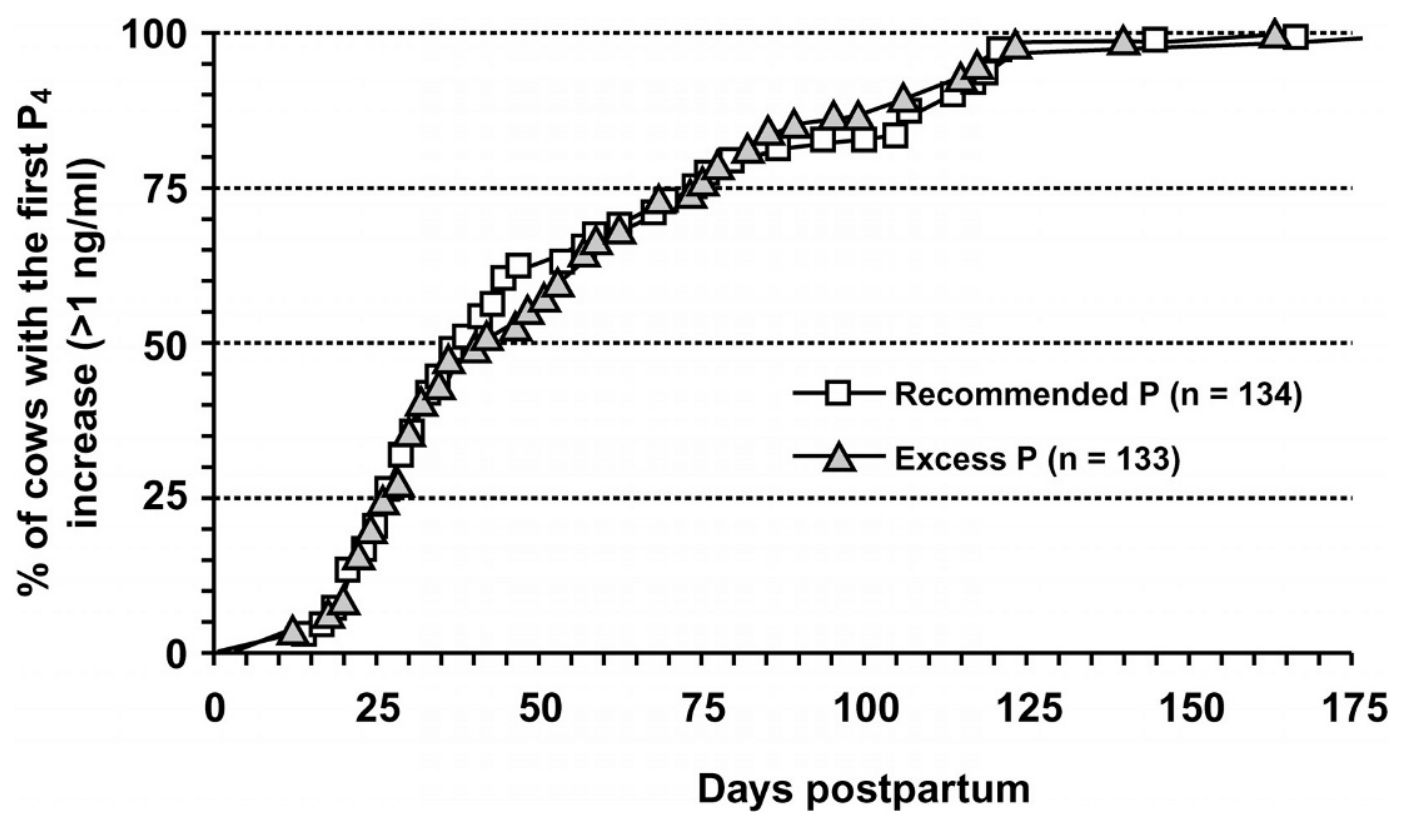

Figure 1. Survival curves $(P=0.66)$ for days to first postpartum increase in $\mathrm{P}_{4}(>1 \mathrm{ng} / \mathrm{ml})$ for cows fed diets containing recommended $(0.37 \%)$ or excess $(0.57 \%) \mathrm{P}$.

firmed for all estrous periods by transrectal ultrasonography. Data provided by the radiotelemetry system were used for retrospective analyses of estrous activity but were not used as a management tool for breeding cattle.

\section{Reproductive Management}

Visual detection of estrus was performed by the farm crew during the day and while cows were in the holding area before milking using standing behavior and mucous discharge as signs of estrus. Information on estrus collected by visual observation was only used to breed cows and not to characterize behavior during estrus. Cows were bred by AI following the a.m.-p.m. rule from 50 to 100 DIM. Open cows that reached 100 DIM were synchronized for estrus using the Ovsynch protocol (Pursley et al., 1995). Each cow received 100 $\mu \mathrm{g}$ i.m. of GnRH (Cystorelin; Merial Limited, Iselin $\mathrm{NJ}$ ), followed $7 \mathrm{~d}$ later by $25 \mathrm{mg}$ i.m. of $\mathrm{PGF}_{2 \alpha}$ (Lutalyse, Pharmacia \& Upjohn Co., Kalamazoo, MI), followed $2 \mathrm{~d}$ later with a second intramuscular treatment of $100 \mu \mathrm{g}$ of $\mathrm{GnRH}$. Artificial insemination occurred 18 to $24 \mathrm{~h}$ after the second GnRH treatment. Analysis was terminated in cows that were still not pregnant at 200 DIM.

Weekly transrectal ultrasonography was performed with a $7.5 \mathrm{MHz}$ probe (Aloka 500 ultrasound machine; Corometrics Medical Systems Inc., Wallingford, CT) starting at 50 DIM and continuing until pregnancy was diagnosed ( $\sim 30 \mathrm{~d}$ post $\mathrm{AI})$. A final ultrasound examination ( $60 \mathrm{~d}$ post AI) was performed to confirm the pregnancy. Information on pregnancy loss, gestation length, gender ratio, and twinning was collected.

Weekly blood samples $(\sim 10 \mathrm{ml})$ were obtained from each cow via coccygeal venipuncture using evacuated tubes (Vacutainer; Becton-Dickinson, Rutherford, NJ) starting 1 wk postpartum and continuing until pregnancy was diagnosed. Samples were centrifuged 1600 $\times g$ for 15 min and serum was collected and stored frozen at $-20^{\circ} \mathrm{C}$ in $10-\mathrm{ml}$ plastic scintillation vials for later radioimmunoassay of progesterone $\left(\mathbf{P}_{4}\right)$. Assay of $\mathrm{P}_{4}$ in serum was performed using solid-phase radioimmunoassay kits (Coat-A-Count Progesterone, Diagnostics Products Corporation, Los Angeles, CA). Mean assay sensitivity, calculated as 2 SD below the mean counts per minute of maximum binding, was $0.02 \mathrm{ng} /$ $\mathrm{mL}$. Intra- and interassay coefficients of variation were 5.2 and $7.7 \%$.

The interval from parturition to first detected increase in $\mathrm{P}_{4}$ above $1 \mathrm{ng} / \mathrm{mL}$ was determined from the weekly blood samples and used as an indication of first ovulation. Days to first natural estrus (from 50 to 100 DIM) were determined from data collected by the radiotelemetry system. Anovulatory condition was defined by the absence of a corpus luteum $(\mathbf{C L})$ during the first 3 weekly ultrasound examinations after 50 DIM and by analyses of $\mathrm{P}_{4}$ concentrations. Anovular cows were not treated between 50 to 100 DIM. After 
100 DIM, they received the Ovsynch protocol (Pursley et al., 1995).

\section{Analysis of Data}

Categorical data were analyzed for treatment effects using the FREQ procedure of SAS with chisquare and Fisher's exact tests. Continuous data were analyzed by the LIFETEST procedure of SAS using both strata and time statements (SAS, 1996). Characteristics of estrous behavior between treatments as well as days to first $\mathrm{P}_{4}$ increase, days to first estrus, and days to first service were analyzed by Student's $t$-test.

\section{RESULTS AND DISCUSSION}

\section{Initiation of Estrous Cycles}

The interval from parturition to first detected increase in $\mathrm{P}_{4}$ was similar for cows fed the recommended and excess $\mathrm{P}$ diets. The first weekly blood sample was taken on average $10 \pm 0.3$ (range 3 to $16 \mathrm{~d}$ ) and $10 \pm$ $0.3 \mathrm{~d}$ (range 1 to $15 \mathrm{~d})$ postpartum $(P=0.96)$ and the first $\mathrm{P}_{4}$ increase $(>1 \mathrm{ng} / \mathrm{mL})$ for the entire experimental period ( 1 to $200 \mathrm{DIM}$ ) was detected on average $53 \pm$ 3.0 and $53 \pm 2.8 \mathrm{~d}$ postpartum for cows fed the recommended and excess $\mathrm{P}$ diets, respectively $(P=0.99$; Table 1). Anovulatory condition was diagnosed in $29.9 \%$ of the cows fed the recommended $\mathrm{P}$ diet and $27.1 \%$ of the cows fed the excess $\mathrm{P} \operatorname{diet}(P=0.61)$. Therefore, in order to estimate days to first $\mathrm{P}_{4}$ increase for cycling cows, additional analyses were performed for ovular and anovular cows in each dietary treatment. No differences for cows fed the recommended and excess $\mathrm{P}$ diets were found for this measure between ovular $(36 \pm 1.6$ vs. $38 \pm 1.7 \mathrm{~d} ; P=0.41)$ and anovular (106 \pm 3.1 vs. $103 \pm 3.0 ; P=0.41)$ cows (Table 1). Furthermore, the rate at which the first $P_{4}$ increase ( $>1 \mathrm{ng} / \mathrm{mL})$ was detected did not differ $(P=0.66)$ between dietary treatments using survival analysis and data from all cows (ovular and anovular; Figure 1). For instance, $50 \%$ of the cows in both dietary treatments had the first $\mathrm{P}_{4}$ increase detected by 40 DIM. Similarly, by 100 DIM, $82.8 \%$ of the cows fed the recommended $\mathrm{P}$ diet and $87.2 \%$ of the cows fed the excess $\mathrm{P}$ diet had the first $\mathrm{P}_{4}$ increase detected (Figure 1). The remaining cows $(17.2 \%$ for the recommended $\mathrm{P}$ group and $12.8 \%$ for the excess $\mathrm{P}$ group; $P=0.32$ ) for which the first increase in $\mathrm{P}_{4}$ was detected after 100 DIM, corresponded to anovular cows (21 and 14 for the recommended and excess $\mathrm{P}$ groups, respectively) that received the Ovsynch program. The majority of these anovular cows (19 and 12 for the recommended and excess $\mathrm{P}$ groups respectively; $P=0.99$ ) had the first $\mathrm{P}_{4}$ increase detected by 125 DIM after they received the first treatment for synchronization of ovulation (Figure 1). However, some of them (1 and 2 for the recommended and excess $\mathrm{P}$ groups, respectively) did not respond to the first but to a subsequent synchronization treatment and for these cows the first $\mathrm{P}_{4}$ increase was detected between 125 and 166 DIM (Figure 1). One cow fed the recommended $\mathrm{P}$ diet did not increase $\mathrm{P}_{4}>1 \mathrm{ng} / \mathrm{mL}$ during the experiment and was censored at 200 DIM (Figure 1).

Previous studies have used the first postpartum $\mathrm{P}_{4}$ increase in milk (Brodison et al., 1989) or blood serum (Carstairs at al., 1980; De Boer et al., 1981) to determine the occurrence of first ovulation for lactating cows fed diets varying in $\mathrm{P}$ content and have obtained varying results. De Boer et al. (1981) reported a tendency for a shorter interval $(19.5 \pm 4 \mathrm{~d})$ to first ovulation for cows fed a diet containing $0.34 \% \mathrm{P}(\mathrm{n}=10)$ as compared to intervals $(28.9 \pm 4$ and $27.7 \pm 4 \mathrm{~d})$ for cows fed diets containing $0.51(\mathrm{n}=8)$ and $0.69 \% \mathrm{P}$ $(n=9)$. In contrast, Carstairs et al. $(1980)$ reported a tendency for a longer interval to first rise in $\mathrm{P}_{4}$ [ranges 47 to $53(n=24)$ vs. 37 to $44 d(n=24)]$ for cows fed a low P diet (85\% of NRC [1971] recommended amount) as compared to cows fed a high P diet (135\% of NRC [1971] recommended amount); additionally, for that study, the interval from parturition to first $\mathrm{P}_{4}$ increase was negatively correlated $(\mathrm{r}=-0.34)$ with blood serum $P$ concentrations. A later study (Brodison et al., 1989) found no effect of dietary $\mathrm{P}(0.40$ to 0.45 vs. 0.60 to $0.64 \%$ ) on intervals to first $\mathrm{P}_{4}$ increase [ranges 33 to $36(n=122)$ vs. 29 to $44 \mathrm{~d}(\mathrm{n}=95)$ ] for lactating cows. Variation in the results for these studies may be related to differences in sample size and level of $\mathrm{P}_{4}$ used as the indicator of luteal activity ( $1 \mathrm{vs} .3 \mathrm{ng} / \mathrm{ml}$ ).

Intervals to first postpartum increase in $\mathrm{P}_{4}$ for the current experiment are longer than those reported previously for lactating dairy cows. However, the mode ( $21 \mathrm{~d}$ ) for this measure as well as the intervals for ovular cows fed the recommended ( $36 \pm 1.6 \mathrm{~d}$ ) and the excess $(38 \pm 1.7 \mathrm{~d}) \mathrm{P}$ diets are within the normal range (17 to $42 \mathrm{~d}$ ) reported in serum (Carstairs at al., 1980; De Boer et al., 1981) and milk (Brodison et al., 1989). This suggests that the extended intervals to first $\mathrm{P}_{4}$ rise observed in the present study were probably caused by cows with long periods to first ovulation (for the current experiment $28.5 \%$ of the cows were anovular by $71 \mathrm{DIM})$. The incidence of anovulatory condition found in the present study is within the range reported (17 to 29\%) for modern lactating dairy cows between 50 and 77 DIM based on serum $\mathrm{P}_{4}(\leq 1$ $\mathrm{ng} / \mathrm{mL}$ ) concentrations in two or three blood samples 
Table 1. Days to first increase in $\mathrm{P}_{4}(>1 \mathrm{ng} / \mathrm{ml}$ ), days to first estrus, and days to first service (mean \pm SEM [range]) for cows fed diets containing recommended $(0.37 \%)$ or excess $(0.57 \%) \mathrm{P}$.

\begin{tabular}{|c|c|c|c|}
\hline & Recommended P & Excess $\mathrm{P}$ & $P$-value \\
\hline Total cows, $\mathrm{n}$ & 134 & 133 & - \\
\hline Anovular cows ${ }^{1}, \%$ & $\begin{array}{l}29.9 \\
(40 / 134)\end{array}$ & $\begin{array}{l}27.1 \\
(36 / 133)\end{array}$ & 0.61 \\
\hline \multicolumn{4}{|c|}{ Days to first $\mathrm{P}_{4}$ increase ${ }^{2}$} \\
\hline All cows & $\begin{array}{l}53 \pm 3.0 \\
{[14 \text { to } 159]} \\
\mathrm{n}=133^{3}\end{array}$ & $\begin{array}{l}53 \pm 2.8 \\
{[16 \text { to } 166]} \\
\mathrm{n}=133\end{array}$ & 0.99 \\
\hline Ovular cows & $\begin{array}{l}36 \pm 1.6 \\
{[14 \text { to } 71]} \\
\mathrm{n}=94\end{array}$ & $\begin{array}{l}38 \pm 1.7 \\
{[16 \text { to } 71]} \\
\mathrm{n}=97\end{array}$ & 0.41 \\
\hline Anovular cows & $\begin{array}{l}106 \pm 3.1 \\
{[78 \text { to } 159]} \\
\mathrm{n}=39\end{array}$ & $\begin{array}{l}103 \pm 3.0 \\
{[78 \text { to } 166]} \\
\mathrm{n}=36\end{array}$ & 0.41 \\
\hline \multicolumn{4}{|c|}{ Days to first recorded estrus ${ }^{4}$} \\
\hline Total cows & $\begin{array}{l}68 \pm 1.1 \\
{[50 \text { to } 92]} \\
\mathrm{n}=103\end{array}$ & $\begin{array}{l}67 \pm 1.2 \\
{[50 \text { to } 99]} \\
\mathrm{n}=109\end{array}$ & 0.87 \\
\hline Ovular cows & $\begin{array}{l}65 \pm 1.2 \\
{[50 \text { to } 92]} \\
\mathrm{n}=79\end{array}$ & $\begin{array}{l}65 \pm 1.5 \\
{[50 \text { to } 97]} \\
\mathrm{n}=86\end{array}$ & 0.84 \\
\hline Anovular cows & $\begin{array}{l}75 \pm 1.8 \\
{[59 \text { to } 92]} \\
\mathrm{n}=24\end{array}$ & $\begin{array}{l}73 \pm 2.8 \\
{[51 \text { to } 99]} \\
\mathrm{n}=23\end{array}$ & 0.68 \\
\hline \multicolumn{4}{|l|}{ Days to first service ${ }^{5}$} \\
\hline Total cows & $\begin{array}{l}89 \mathrm{~m} \pm 2.0 \\
{[50 \text { to } 118]} \\
\mathrm{n}=127\end{array}$ & $\begin{array}{l}90 \pm 2.0 \\
{[50 \text { to } 130]} \\
\mathrm{n}=131\end{array}$ & 0.87 \\
\hline Ovular cows & $\begin{array}{l}83 \pm 2.4 \\
{[50 \text { to } 118]} \\
\mathrm{n}=89\end{array}$ & $\begin{array}{l}85 \pm 2.5 \\
{[50 \text { to } 130]} \\
\mathrm{n}=96\end{array}$ & 0.60 \\
\hline Anovular cows & $\begin{array}{l}103 \pm 2.5 \\
{[63 \text { to } 117]} \\
\mathrm{n}=38\end{array}$ & $\begin{array}{l}102 \pm 2.7 \\
{[53 \text { to } 126]} \\
\mathrm{n}=35\end{array}$ & 0.82 \\
\hline
\end{tabular}

\footnotetext{
${ }^{1}$ Anovulatory condition was determined by the absence of a CL during the first three weekly ultrasound examinations after $\mathrm{d} 50$.

${ }^{2}$ First increase in $\mathrm{P}_{4}$ concentration $>1 \mathrm{ng} / \mathrm{ml}$.

${ }^{3}$ One cow that did not increase $\mathrm{P}_{4}>1 \mathrm{ng} / \mathrm{ml}$ during the experiment is not included.

${ }^{4}$ Natural estrous periods detected by radiotelemetry between d 50 and 100 .

${ }^{5}$ Based on visual detection of estrus by the farm crew.
}

taken 7 to $10 \mathrm{~d}$ apart (Moreira et al., 2001; Pursley et al., 2001).

Intervals to first detected estrus were calculated using the data collected by the radiotelemetry system between 50 and 100 DIM. This reproductive measure was similar $(67 \pm 1.2$ vs. $68 \pm 1.1 \mathrm{~d} ; P=0.87)$ for cows fed the excess and the recommended $\mathrm{P}$ diets, respectively (Table 1 ). The rate at which the first estrus was detected did not differ $(P=0.24)$ between dietary treatments when data for all cows were used in a survival analysis (Figure 2). For instance, by 71 DIM, $50 \%$ of the cows in both experimental groups had an estrus recorded. Similarly, between 50 and 100 DIM, 76.9\% of the cows fed the recommended $\mathrm{P}$ diet and $82.0 \%$ of the cows fed the excess $\mathrm{P}$ diet had an estrus detected (Figure 2). The remaining cows (23.1\% for the recommended $\mathrm{P}$ treatment and $18.0 \%$ for the excess $\mathrm{P}$ treatment; $P=0.30$ ) corresponded to ovular (15 and 11 cows for the recommended and excess $P$ treatment, respectively) and anovular (16 and 13 cows for the recommended and excess $P$ treatment, respectively) cows with no estrous activity recorded by 100 DIM (Figure 2).

In the present study 35.0 and $36.1 \%$ of the anovular cows in the recommended and excess $P$ treatments $(P=0.92)$ had at least one estrus recorded without a corresponding ovulation. Thus, additional analyses for days to first estrus were performed using only ovular cows with an estrus recorded between 50 and 100 DIM. No differences were found for this measure $(65$ \pm 1.2 vs. $65 \pm 1.5 \mathrm{~d} ; P=0.84)$ or the rate at which these periods of estrus were detected $(P=0.38)$ for cows fed the recommended and excess $\mathrm{P}$ diets, respectively (Table 1). 


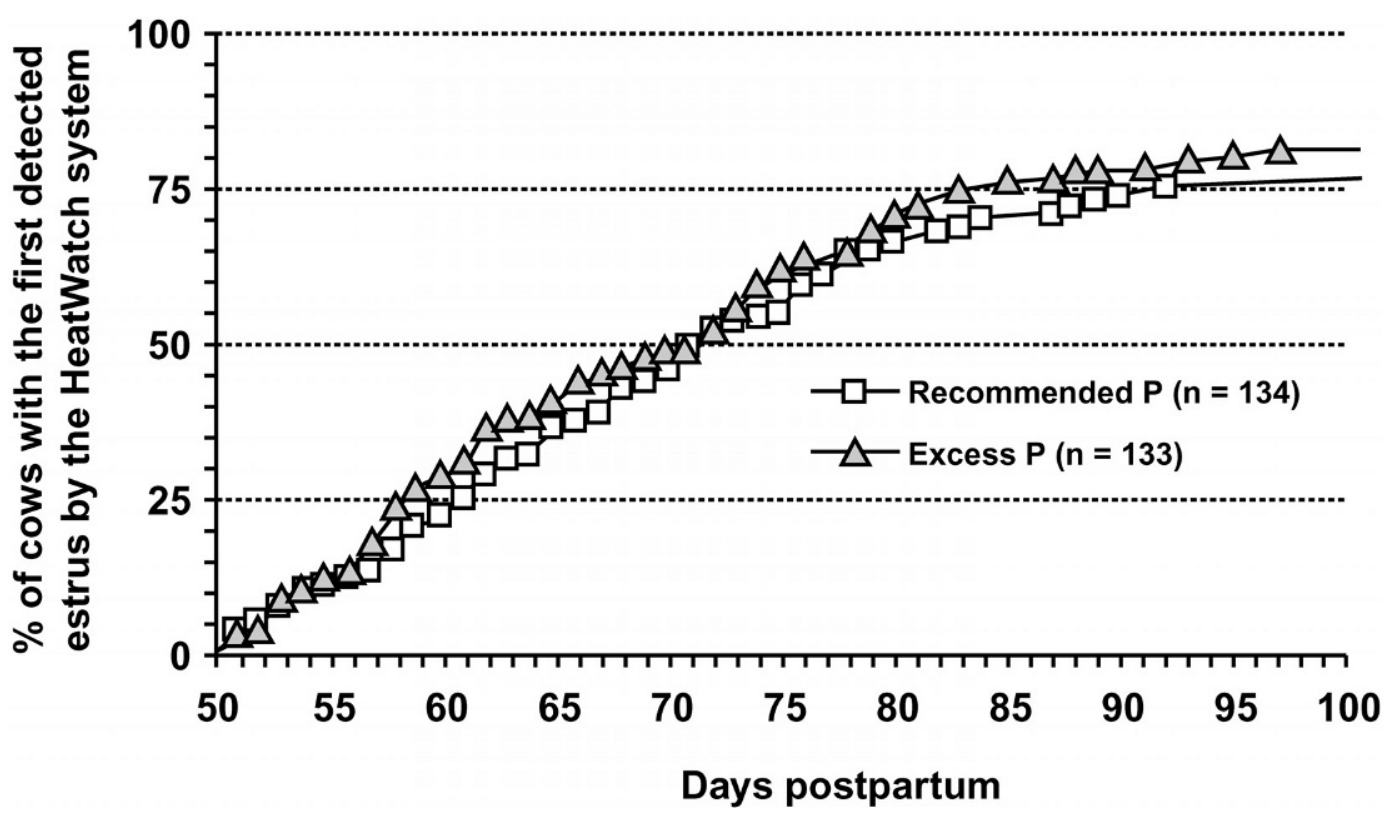

Figure 2. Survival curves $(P=0.24)$ for days to first estrus detected by the HeatWatch system between d 50 and d 100 for cows fed diets containing recommended $(0.37 \%)$ or excess $(0.57 \%) \mathrm{P}$.

Previous studies have reported varying results on the effect of dietary $\mathrm{P}$ on interval to first observed estrus in dairy cattle (De Boer et al., 1981; Call et al., 1987; Wu and Satter, 2000). One study found no differences for this measure [44.7 $(\mathrm{n}=11), 54.4(\mathrm{n}=$ $8)$, and $32 \mathrm{~d}(\mathrm{n}=11)]$ between cows fed diets varying in $\mathrm{P}$ content (0.34, 0.51, or 0.69\%; De Boer et al., 1981). Similarly, Wu and Satter (2000) reported no effect of dietary $\mathrm{P}$ level $(0.38$ vs. $0.48 \%)$ on average days to first observed estrus [52.2 $(\mathrm{n}=21)$ vs. $43.4 \mathrm{~d}(\mathrm{n}=21)$ ] in lactating dairy cows. In contrast, Call et al. (1987) reported a tendency for a shorter interval $(45 \mathrm{~d})$ to first observed estrus for cows fed a diet containing $0.24 \% \mathrm{P}(\mathrm{n}=12)$ compared with intervals (66 and 50 d) for cows fed diets containing $0.32(\mathrm{n}=7)$ and $0.42 \%$ $\mathrm{P}(\mathrm{n}=10)$, respectively. Inconsistent results for these studies, probably related to limited sample size and variation in the system used to detect estrus (duration and frequency of visual observation), preclude drawing conclusions about a relationship between dietary $\mathrm{P}$ and interval to first observed estrus. Our study used a radiotelemetric system to monitor cows $24 \mathrm{~h} / \mathrm{d}$ for estrus, included more than twice the number of cows of any of these previous studies, and provided more precise data on the occurrence of ovulation after each estrus (as determined by ultrasound and serum $\mathrm{P}_{4}$ concentrations).

\section{Characteristics of Estrous Behavior}

The radiotelemetry system detected estrous activity for $189(80.1 \%)$ and 213 (78.3\%) of the natural ovula- tions recorded for cows fed the recommended and excess $\mathrm{P}$ diets $(P=0.62)$. These estrous periods were recorded on average $98.6 \pm 3.1 \mathrm{~d}$ (range 50 to $196 \mathrm{~d}$ ) and $93.9 \pm 2.8 \mathrm{~d}$ (range 50 to $192 \mathrm{~d})(P=0.25)$ postpartum, respectively. Within these estrous periods, 30 (15.9\%) for the recommended and $39(18.3 \%)$ for the excess $\mathrm{P}$ groups consisted of one mount and were removed from the analysis on estrous characteristics $(P=0.52)$. For the remaining 159 and 174 periods of estrus for cows fed the recommended and excess $\mathrm{P}$ diets, the length of estrus was $8.7 \pm 0.5$ and $8.7 \pm 0.7 \mathrm{~h}(P=0.99)$, and the number of mounts per estrus was $7.4 \pm 0.5$ and $7.8 \pm 0.5(P=0.57)$ for a total mounting time during estrus of $25.8 \pm 1.8$ and $24.5 \pm 1.6 \mathrm{~s}(P=0.59)$ (Table 2). Similar duration of estrus $(9.5 \pm 0.8$ and $8.6 \pm 0.4$ h), number of mounts (10.1 \pm 0.6 and $11.2 \pm 0.9$ ), and mounting duration $(24.1 \pm 1.5$ and $29.0 \pm 2.7 \mathrm{~s})$ to those found in the present study have been reported

Table 2. Characteristics of estrous events (mean \pm SEM [range]) for cows fed diets containing recommended $(0.37 \%)$ or excess $(0.57 \%) \mathrm{P}$.

\begin{tabular}{|c|c|c|c|}
\hline Characteristic & $\begin{array}{l}\text { Recommended } \mathrm{P} \\
\mathrm{n}=159\end{array}$ & $\begin{array}{l}\text { Excess } \mathrm{P} \\
\mathrm{n}=174\end{array}$ & $P$-value \\
\hline Duration of estrus ${ }^{1}, h$ & $\begin{array}{c}8.7 \pm 0.5 \\
{[0.4 \text { to } 23.7]}\end{array}$ & $\begin{array}{c}8.7 \pm 0.7 \\
{[0.4 \text { to } 26.5]}\end{array}$ & 0.99 \\
\hline Total mounts, $\mathrm{n}$ & $\begin{array}{l}7.4 \pm 0.5 \\
{[2 \text { to } 30]}\end{array}$ & $\begin{array}{l}7.8 \pm 0.5 \\
{[2 \text { to } 44]}\end{array}$ & 0.57 \\
\hline Total mounting time, $\mathrm{s}$ & $\begin{array}{l}25.8 \pm 1.8 \\
{[4 \text { to } 136]}\end{array}$ & $\begin{array}{l}24.5 \pm 1.6 \\
{[4 \text { to } 138]}\end{array}$ & 0.59 \\
\hline
\end{tabular}

${ }^{1}$ Number of hours between the first and the last recorded mount of an estrous period. 
Table 3. The distribution of estrous periods categorized by duration and intensity for cows fed diets containing recommended $(0.37 \%)$ or excess $(0.57 \%) \mathrm{P}$.

\begin{tabular}{lllll}
\hline & Recommended P & \multicolumn{2}{c}{ Excess P } & $\%$ \\
\hline Estrus category $^{1}$ & $\mathrm{n}=159$ & $\%$ & $\mathrm{n}=174$ & 43.7 \\
\hline Short duration, low intensity & 59 & 37.1 & 76 & 20.7 \\
Short duration, high intensity & 30 & 18.9 & 36 & 24.7 \\
Long duration, low intensity & 42 & 26.4 & 43 & 10.9 \\
Long duration, high intensity & 28 & 17.6 & 19 & \\
\hline
\end{tabular}

${ }^{1}$ Periods of estrus were classified by duration as short $(<8.7 \mathrm{~h})$ or long $(\geq 8.7 \mathrm{~h})$. Short periods of estrus were classified as low $(<2.7 \mathrm{~m} / \mathrm{h})$ or high $(\geq 2.7 \mathrm{~m} / \mathrm{h})$ intensity and long periods of estrus as low $(<0.6 \mathrm{~m} / \mathrm{h})$ or high $(\geq 0.6 \mathrm{~m} / \mathrm{h})$ intensity.

using a similar system for estrus detection for dairy cows in confinement (Walker et al., 1996) and pasture (Xu et al., 1998), respectively.

The effect of dietary $\mathrm{P}$ level on estrous behavior has been investigated in lactating dairy cows (Lopez et al., 2001) and heifers (Hurley et al., 1982). Lopez et al. (2001) reported no effect of dietary P level (0.38 vs. $0.48 \%)$ on duration of estrus $(9.1 \pm 1.0$ vs. $8.8 \pm 1.1 \mathrm{~h}$ ), number of mounts ( $7.5 \pm 1.2$ vs. $8.0 \pm 1.5)$, and mounting time ( $29.6 \pm 1.0 \mathrm{vs} .31 .9 \pm 5.8 \mathrm{~s})$ for lactating dairy cows $(\mathrm{n}=42)$ using a similar system for estrus detection. Similarly, Hurley et al. (1982) reported no differences in duration and intensity of estrus for dairy heifers $(\mathrm{n}=48)$ fed diets varying in $\mathrm{P}$ content $(0.19$, 0.37 , or $0.64 \%$ ) when continuous visual observation of estrus was implemented. Results from these studies and from the present experiment suggest that characteristics (duration, number of mounts, and mounting time) of estrus are not improved for cows fed a diet containing excess $\mathrm{P}$ compared with cows fed recommended amounts of $\mathrm{P}$.

The effect of dietary $\mathrm{P}$ treatment on duration and intensity of estrus was analyzed. In general, cows with shorter duration of estrus had a higher intensity of estrus [as determined by the number of mounts $/ \mathrm{h}(\mathrm{m} /$ h)] than cows with longer duration of estrus $(P<$ 0.0001). Therefore, the intensity of estrus was classified separately for cows with short or long periods of estrus. The average duration of estrus was calculated $(8.7 \mathrm{~h})$ and estrous events were classified by duration as short $(<8.7 \mathrm{~h})$ or long $(\geq 8.7 \mathrm{~h})$. The mean intensity for short periods of estrus was calculated $(2.7 \mathrm{~m} / \mathrm{h})$ and short periods of estrus were classified by intensity as low $(<2.7 \mathrm{~m} / \mathrm{h})$ or high $(\geq 2.7 \mathrm{~m} / \mathrm{h})$. Similarly, the mean intensity for long periods of estrus was calculated $(0.6 \mathrm{~m} / \mathrm{h})$ and long periods of estrus were classified by intensity as low $(<0.6 \mathrm{~m} / \mathrm{h})$ or high $(\geq 0.6 \mathrm{~m} / \mathrm{h})$. The distribution of periods of estrus by duration and/ or intensity did not differ between cows fed the recommended or excess $\mathrm{P}$ diets $(P=0.29)$ (Table 3$)$. There were $89(55.9 \%)$ and $112(64.4 \%)$ short periods of estrus and $70(44.1 \%)$ and $62(35.6 \%)$ long periods of estrus for cows fed the recommended and excess $\mathrm{P}$ diets, respectively $(P=0.19)$. Within the short periods of estrus, there were $59(66.3 \%)$ and $76(67.9 \%)$ lowintensity periods of estrus and $30(33.7 \%)$ and 36 (32.1\%) high-intensity periods of estrus for cows fed the recommended and excess $\mathrm{P}$ diets, respectively $(P=$ 0.81 ). Within the long periods of estrus, there were 42 $(60.0 \%)$ and $43(69.4 \%)$ low-intensity periods of estrus and $28(40.0 \%)$ and $19(30.6 \%)$ high-intensity periods of estrus for cows fed the recommended and excess $\mathrm{P}$ diets, respectively $(P=0.26)$. Comparable distributions have been reported (Dransfield et al., 1998; Lopez et al., 2001). The distribution of estrous periods may offer some explanation for the low estrous detection efficiency currently obtained by visual observation since the majority of the periods of estrus are in the category least likely to be detected (short in duration and low in intensity).

\section{Conception Rate and Pregnancy Loss}

The timing of AI was based on detection of estrus by visual observation after the voluntary waiting period ( $>50$ DIM) and not on the data collected by the radiotelemetry system. Days to first service $(89 \pm 2.0$ vs. 90 $\pm 2.0 \mathrm{~d} ; P=0.87)$, conception rate to first service (39.4 and $42.0 \% ; P=0.67$ ), as well as overall conception rates at $30(34.3$ vs. $38.0 \% ; P=0.35)$ and at $60 \mathrm{~d}$ (29.1 vs. $31.8 \% ; P=0.47$ ) were similar for cows in the recommended and excess $\mathrm{P}$ groups, respectively (Tables 1 and 4). Cows for both dietary treatments received the first service at a similar rate $(P=0.73$; Figure 3). For instance, $50 \%$ of the cows fed the recommended and excess $\mathrm{P}$ diets received the first service by 98 and 92 DIM, respectively. Similarly, the percentage of cows that reached 100 DIM without a service (43.2 vs. $42.9 \% ; P=0.94)$ as well as the percentage of cows that were not inseminated during the entire experiment $(5.2 \%$ vs. $1.5 \% ; P=0.17)$ did not differ between dietary treatment groups (Figure 3 ). The percentage of cows that were never bred corresponded to cows ( 7 and 2 cows for the recommended and excess 
Table 4. Reproductive parameters (mean \pm SEM) for cows fed diets containing recommended $(0.37 \%)$ or excess $(0.57 \%) \mathrm{P}$.

\begin{tabular}{|c|c|c|c|}
\hline Reproductive parameter & Recommended P & Excess $\mathrm{P}$ & $P$-value \\
\hline Conception rate at first $\mathrm{AI}^{1}, \%$ & $\begin{array}{l}39.4 \\
(50 / 127)\end{array}$ & $\begin{array}{l}42.0 \\
(55 / 131)\end{array}$ & 0.67 \\
\hline Overall conception rate at $30 \mathrm{~d}^{2}, \%$ & $\begin{array}{l}34.3 \\
(99 / 289)\end{array}$ & $\begin{array}{l}38.0 \\
(111 / 292)\end{array}$ & 0.35 \\
\hline Overall conception rate at $60 \mathrm{~d}^{3}, \%$ & $\begin{array}{l}29.1 \\
(84 / 289)\end{array}$ & $\begin{array}{l}31.8 \\
(93 / 292)\end{array}$ & 0.47 \\
\hline Pregnancies lost ( 30 to $60 \mathrm{~d}$ ), $\%$ & $\begin{array}{l}15.2 \\
(15 / 99)\end{array}$ & $\begin{array}{l}16.2 \\
(18 / 111)\end{array}$ & 0.83 \\
\hline Pregnancies lost after $60 \mathrm{~d}, \%$ & $\begin{array}{l}7.1 \\
(6 / 84)\end{array}$ & $\begin{array}{l}7.5 \\
(7 / 93)\end{array}$ & 0.92 \\
\hline Days open for pregnant cows & $\begin{array}{l}112 \pm 3.5 \\
(\mathrm{n}=99)\end{array}$ & $\begin{array}{l}116 \pm 3.8 \\
(\mathrm{n}=111)\end{array}$ & 0.45 \\
\hline Services/conception for pregnant cows ${ }^{4}$ & $\begin{array}{l}2.9 \\
(289 / 99)\end{array}$ & $\begin{array}{l}2.6 \\
(292 / 111)\end{array}$ & 0.35 \\
\hline Gestation length, $d$ & $\begin{array}{l}279 \pm 0.6 \\
(\mathrm{n}=73)\end{array}$ & $\begin{array}{l}279 \pm 0.5 \\
(\mathrm{n}=79)\end{array}$ & 0.96 \\
\hline Female:male ${ }^{5}, \%$ & $\begin{array}{l}45.6: 54.4 \\
(\mathrm{n}=68)\end{array}$ & $\begin{array}{l}48.6: 51.4 \\
(\mathrm{n}=74)\end{array}$ & 0.71 \\
\hline Multiple ovulation rate, $\%$ & $\begin{array}{l}21.6 \\
(51 / 236)\end{array}$ & $\begin{array}{l}19.5 \\
(53 / 272)\end{array}$ & 0.55 \\
\hline Twinning rate, $\%$ & $\begin{array}{l}6.8 \\
(\mathrm{n}=5)\end{array}$ & $\begin{array}{l}6.4 \\
(\mathrm{n}=5)\end{array}$ & 0.91 \\
\hline Estrous cycle length, $d$ & $\begin{array}{l}23 \pm 0.6 \\
(\mathrm{n}=108)\end{array}$ & $\begin{array}{l}23 \pm 0.5 \\
(\mathrm{n}=103)\end{array}$ & 0.70 \\
\hline
\end{tabular}

${ }^{1}$ Number of pregnancies detected at $30 \mathrm{~d}$ divided by the number of first services.

${ }^{2}$ Number of pregnancies detected at $30 \mathrm{~d}$ divided by the total number of services.

${ }^{3}$ Number of pregnancies detected at $60 \mathrm{~d}$ divided by the total number of services.

${ }^{4}$ Total number of services divided by the number of pregnancies detected at $30 \mathrm{~d}$.

${ }^{5}$ Gender ratio for single births.

P groups, respectively) that were removed from the experiment before 100 DIM, when ovulation was synchronized and timed AI was applied. Inseminations applied after ovulation was synchronized ( $>100$ DIM) increased the rate at which cows received the first service (Figure 3 ). In total, $38.0 \%$ of the cows fed recommended $\mathrm{P}$ and $41.3 \%$ of the cows fed excess $\mathrm{P}$ received first service after ovulation was synchronized $(P=0.58)$.

Previous studies have reported varying results on the effect of dietary $\mathrm{P}$ on conception rate to first service and overall conception rates for dairy cattle (Hignett and Hignett, 1952; Morrow, 1969; Noller et al., 1977). An early field study reported increased conception rates to first service ( 20\%) in herds fed $\mathrm{P}$ in amounts below current NRC (2001) requirements. First-service conception rate did not improve further once an amount of $\mathrm{P}$ roughly corresponding to current NRC (2001) requirements was fed (Hignett and Hignett, 1952). Another study related low $P$ intake to reduced conception rates at 30 and $60 \mathrm{~d}$ in yearling dairy heifers diagnosed with $\mathrm{P}$ deficiency (Morrow, 1969). However, such a relationship was not detected in a later study (Noller et al., 1977) when healthy dairy heifers were fed diets with (0.32 to $0.43 \%$ ) or without P supplementation $(0.21$ to $0.30 \%)$. Later research (Brodison et al., 1989) reported similar days to first service (ranges 74 to 79 vs. 74 to $83 \mathrm{~d}$ ) and conception rates to first service (ranges 52 to 63 vs. 57 to $63 \%$ ) as well as overall conception rates (ranges 59 to 76 vs. 59 to $68 \%$ ) for cows fed diets containing low (0.40 to $0.45 \%$ ) or high P $(0.60$ to $0.64 \%)$ during 3 yr. Similarly, a recent study (Wu and Satter, 2000) reported no effect of dietary P level ( 0.38 vs. $0.48 \%$ ) on intervals (ranges 72.2 to 76.8 vs. 65.6 to $76.4 \mathrm{~d}$ ) and conception rates to first service (ranges 28.6 to 42.3 vs. 28.0 to $42.9 \%$ ) for lactating cows during two lactations. Inconsistency in the results for these studies may be related to experimental conditions and sample size. Early reports (Hignett and Hignett, 1952; Morrow, 1969) were the compilation of general field observations, while recent reports (Brodison et al., 1989; Wu and Satter, 2000) presented experimental data obtained under more properly controlled conditions where $\mathrm{P}$ was the only limiting factor. Sample size in the controlled experiments do not provide sufficient statistical power to 


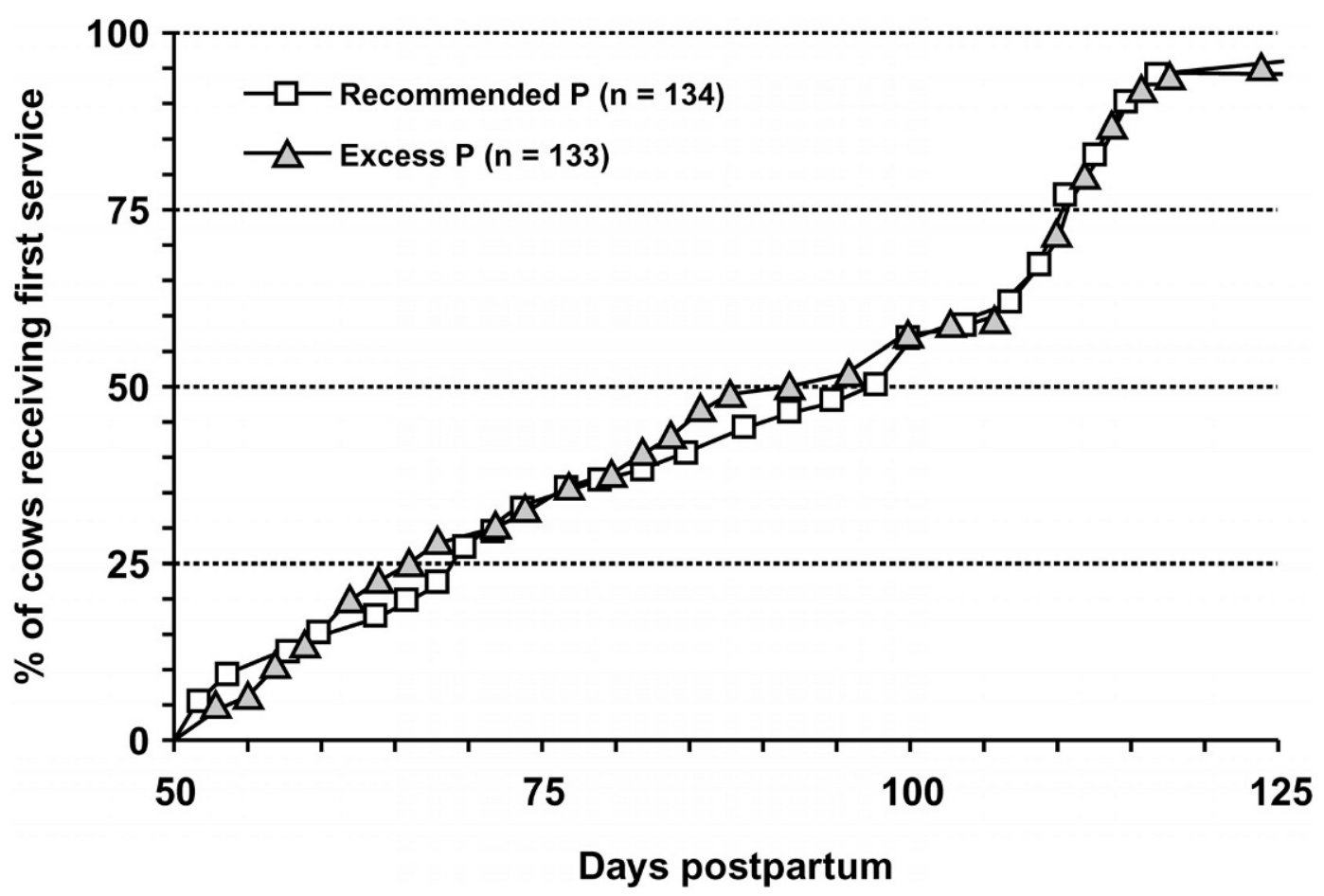

Figure 3. Survival curves $(P=0.73)$ for days to first service for cows fed diets containing recommended $(0.37 \%)$ or excess $(0.57 \%)$ P.

test the relationship between dietary $\mathrm{P}$ and conception rates for dairy cattle because binomial variables such as conception rate require larger data sets for valid analysis (Wu and Satter, 2000). To our knowledge, the present study is the largest evaluating the relationship between dietary $\mathrm{P}$ and conception rates of lactating dairy cows under controlled experimental conditions. Our results, in agreement with some from previous studies, suggest that conception rate is not improved for dairy cows fed diets containing excess $\mathrm{P}$ compared with cows fed diets containing recommended $\mathrm{P}$.

There were $15(15.2 \%)$ and $18(16.2 \% ; P=0.83)$ pregnancies lost between 30 and $60 \mathrm{~d}$ and $6(7.1 \%)$ and $7(7.5 \% ; P=0.92)$ pregnancies lost after $60 \mathrm{~d}$ for the recommended and excess $\mathrm{P}$ groups, respectively (Table 4). The percentage of pregnancies lost between 30 and $60 \mathrm{~d}$ observed in the present study is within the normal range (10 to $16 \%$ ) reported for lactating dairy cows during the same period (Vasconcelos et al., 1997; Fricke et al., 1998; Moreira et al., 2001). Similarly, the percentage of pregnancies lost after 60 $\mathrm{d}$ is comparable to another report (3.6\% from 56 to 98 $\mathrm{d}$ and $5.5 \%$ from $98 \mathrm{~d}$ to calving) for lactating dairy cows (Vasconcelos et al., 1997).

\section{Other Reproductive Measures}

Days open were not reduced $(P=0.45)$ for pregnant cows fed the excess $\mathrm{P}$ diet (116 $\pm 3.8 \mathrm{~d})$ compared with pregnant cows fed the recommended $\mathrm{P}$ diet $(112 \pm 3.5$; Table 4). Similarly, the rate at which cows became pregnant did not differ $(P=0.48)$ between treatment groups (Figure 4). For instance, by 100 DIM, 25.4\% of the cows in the recommended $\mathrm{P}$ treatment and $30.8 \%$ of the cows in the excess $\mathrm{P}$ treatment had conceived. After 100 DIM, pregnancies from the Ovsynch protocol increased the rate at which cows conceived (Figure 4). In total, $44.8 \%$ of the cows fed the recommended $\mathrm{P}$ diet and $43.6 \%$ of the cows fed the excess $\mathrm{P}$ diet conceived after 100 DIM $(P=0.85)$. At the end of the experimental period (200 DIM), $29.8 \%$ of the cows in the recommended $P$ treatment and $25.6 \%$ of the cows in the excess $\mathrm{P}$ treatment were censored as nonpregnant (Figure 4). These cows corresponded to animals that were inseminated and did not conceive (38 and 27 cows for the recommended and excess $\mathrm{P}$ diets, respectively) and cows that were never bred during the experiment ( 7 and 2 cows for the recommended and excess $\mathrm{P}$ diets, respectively) because they were removed before 100 DIM when ovulation was synchronized and timed AI was applied.

Previous studies have analyzed the relationship between dietary $\mathrm{P}$ level and days open for dairy cows (Brodison et al., 1989; Wu and Satter, 2000). Wu and Satter (2000) reported no effect of dietary P level ( 0.38 vs. $0.48 \%)$ on days open [ranges 103 to $115(\mathrm{n}=47)$ vs. 105 to $120 \mathrm{~d}(\mathrm{n}=48)$ ]. Similarly, Brodison et al. 


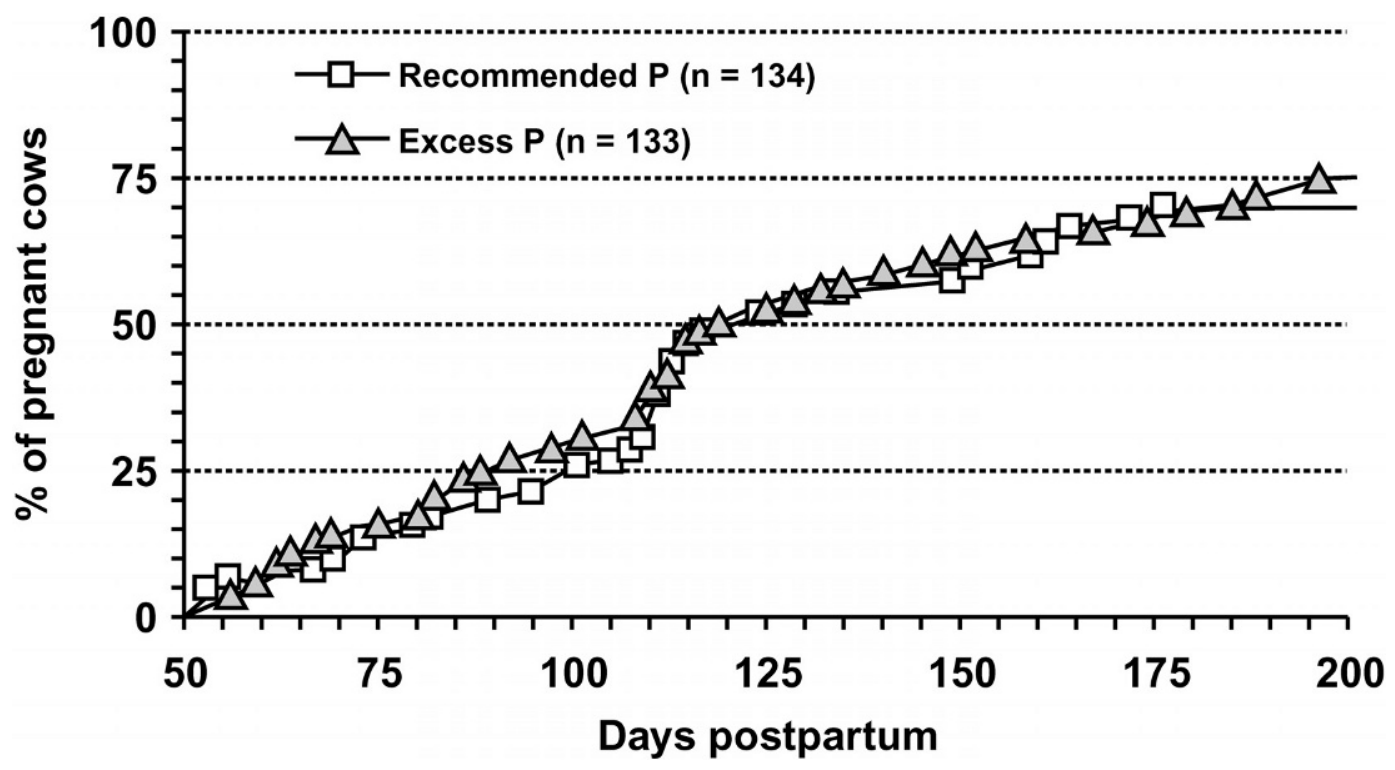

Figure 4. Survival curves $(P=0.48)$ for days open for cows fed diets containing recommended $(0.37 \%)$ or excess $(0.57 \%) \mathrm{P}$.

(1989) found no differences for intervals from calving to conception [ranges 85 to $95(\mathrm{n}=122)$ vs. 90 to 103 $\mathrm{d}(\mathrm{n}=95)]$ between cows fed 0.40 to $0.45 \% \mathrm{P}$ or 0.60 to $0.64 \% \mathrm{P}$ in the diets.

There were 236 and 272 natural ovulations recorded for cows fed the recommended and excess $P$ diets. The incidence of multiple ovulations for these groups was 21.6 and $19.5 \%$, respectively $(P=0.55$; Table 4$)$. Similar multiple ovulation rates (9.5 to $20.3 \%)$ to those observed in the present experiment have been reported for lactating dairy cows (Fricke and Wiltbank, 1999; Wiltbank et al., 2000).

Dietary $\mathrm{P}$ level did not alter $(P=0.70)$ the duration of estrous cycles for cows fed the recommended $(23 \pm$ $0.6 \mathrm{~d}$; range 14 to $30 \mathrm{~d})$ and excess $\mathrm{P}(23 \pm 0.5 \mathrm{~d}$; range 14 to $31 \mathrm{~d}$ ) diets (Table 4 ). These results are in agreement with those from previous studies that reported no effect of dietary P level $(0.38 \mathrm{vs} .48 \%)$ on the duration of estrous cycles $[22 \pm 0.8(\mathrm{n}=41)$ vs. 21 $\pm 0.6 \mathrm{~d}(\mathrm{n}=40)$ ] for lactating cows; or for yearling dairy heifers $(\mathrm{n}=115)$ offered dicalcium phosphate ad libitum (Morrow, 1969; Lopez et al., 2001).

There were 154 and 146 synchronization protocols (Ovsynch) applied for the recommended and excess P groups. Ovulation was synchronized in 134 (87.0\%) and $127(86.9 \%)$ of these protocols, respectively $(P=$ $0.99)$. Conception rates at $30(33.1$ vs. $37.0 \% ; P=0.48)$ and at $60 \mathrm{~d}(28.6$ vs. $31.5 \% ; P=0.58)$ did not differ between synchronized ovulations for the recommended and excess $P$ treatments. Similarly, the number of pregnancies lost between 30 and $60 \mathrm{~d}$ [13.7\% (7 of 51 cows) for the recommended vs. $14.8 \%$ ( 8 of 54 cows) for the excess $P$ treatment; $P=0.87$ ] and after $60 \mathrm{~d}$ [6.8\% (3 of 44 cows) for the recommended vs. $10.8 \%$ (5 of 46 cows) for the excess $P$ treatment; $P=$ $0.71]$, for cows that conceived after ovulation was synchronized, was similar between treatment groups.

Synchronization rates similar to those obtained in the present experiment have been reported for the same protocol (80 to $90 \%$ ) in lactating dairy cows (Fricke and Wiltbank, 1999; Pursley et al., 2001). Similarly, comparable conception rates at 28 to $32 \mathrm{~d}$ (36 to $41 \%$ ) and at 60 to $74 \mathrm{~d}$ ( 30 to $34 \%$ ) as well as pregnancies lost (13\%) for the corresponding periods have been reported when the same protocol is used in lactating dairy cows (Fricke et al., 1998; Moreira et al., 2001).

Gestation length $(279 \pm 0.6$ vs. $279 \pm 0.5 ; P=0.88)$, the proportion of female to male calves $(45.6: 54.4 \mathrm{vs}$. 48.6:51.4; $P=0.71$ ), as well as twinning rate (6.8 vs. $6.4 \% ; P=0.91$ ) did not differ between cows fed the recommended and excess $\mathrm{P}$ diets, respectively (Table 4). Gender ratio (female:male) as well as the incidence of twin births for the current experiment are similar to results from previous reports of lactating dairy cows (Pursley et al., 1998; Wiltbank et al., 2000). In general, dietary $\mathrm{P}$ level did not influence any of these reproductive measures in the present experiment.

\section{General Discussion}

Results of this study clearly refute our overall hypothesis that cows fed a diet containing an excess concentration of $\mathrm{P}(0.57 \%)$ would have better reproductive performance compared with cows fed a diet containing 
the NRC recommended $\mathrm{P}(0.37 \%)$ concentration. This contradicts a widely held notion that feeding high $\mathrm{P}$ diets can improve reproductive performance of the herd. This concept may have originated from studies between 1930 and 1950 in which low dietary $\mathrm{P}$ was related to reduced first service conception rate, or to long periods of anestrus and/or irregular expression of estrus, or to decreased calf crops in range cattle (Eckles et al., 1932; Hignett and Hignett, 1952). In these early studies, dietary $\mathrm{P}$ was extremely low, and other dietary deficiencies associated with the low quality diets that were fed may have contributed to the reduced reproductive performance (Palmer et al., 1941). It has been reported that dietary $P$ levels of less than approximately $0.25 \%$ can reduce rumen microbial growth (Durand and Kawashima, 1980) resulting in less microbial protein, lowered ration digestibility, and decreased energy supply. Additionally, low levels of dietary $\mathrm{P}$ can reduce feed intake causing coincidental deficiencies of energy, protein, and other nutrients. Decreases in DMI, milk production, and BW have been reported for dairy cows fed a diet containing $0.24 \% \mathrm{P}$ when compared to cows fed diets ranging from 0.28 to $0.42 \%$ (Call et al., 1987; Valk and Sebek, 1999). It is probably through these mechanisms that low levels of dietary P may have an indirect effect on reproductive performance in the range cattle utilized in early reports. However, the $\mathrm{P}$ content of modern dairy diets is usually above the low $\mathrm{P}$ levels that might impair function of rumen microbes or depress DMI. The $\mathrm{P}$ content in current dairy diets usually ranges from 0.33 to $0.40 \%$ before $\mathrm{P}$ supplementation (Wu and Satter, 2000). Therefore, supplementation of $P$ above the NRC recommendations is not an appropriate practice to improve reproductive performance in modern dairies.

\section{CONCLUSIONS}

Feeding of a diet containing excess $\mathrm{P}(0.57 \%)$ does not improve reproductive performance of lactating dairy cows as compared to cows fed a diet meeting NRC requirements $(0.37 \%)$. Feeding of diets to meet NRC (2001) $P$ requirements can reduce the $P$ content in manure and therefore the risk of environmental damage (eutrophication of surface waters). In addition, elimination or reduction of $\mathrm{P}$ supplementation can reduce the cost of dairy cattle diets.

\section{ACKNOWLEDGMENTS}

The authors thank employees at the US Dairy Forage Research Center farm at Prairie du Sac, WI, for feed preparation and animal care; and Mary Becker,
Matias Aguerre, Hendrick Henselmeyer, Zachary Schott, Kathleen Herbert, and Amber Rew for technical support. Appreciation is extended to USDACREES National Research Initiative, Agricultural Systems Research Program (Grant \# 9703968) for partial funding of this study.

\section{REFERENCES}

Association of Official Agricultural Chemists. 1980. Official Methods of Analysis. 13th ed. AOAC, Washington, D.C.

Brodison, J. A., E. A. Goodall, J. D. Armstrong, D. I. Givens, F. J. Gordon, W. J. McCaughey, and J. R. Todd. 1989. Influence of dietary phosphorus on the performance of lactating dairy cattle. J. Agric. Sci. (Camb.) 112:303-311.

Call, J. W., J. E. Butcher, J. L. Shupe, R. C. Lamb, R. L. Boman, and A. E. Olson. 1987. Clinical effects of low dietary phosphorus concentrations in feed given to lactating dairy cows. Am. J. Vet. Res. 48:133-136.

Carstairs, J. A., D. A. Morrow, and R. S. Emery. 1980. Postpartum reproductive function of dairy cows as influenced by energy and phosphorus status. J. Dairy Sci. 51:1122-1130.

De Boer, G., J. G. Buchanan-Smith, G. K. Macleod, and J. S. Walton. 1981. Responses of dairy cows fed alfalfa silage supplemented with phosphorus, copper, zinc, and manganese. J. Dairy Sci. 64:2370-2377.

Dransfield, M. B. G., R. L. Nebel, R. E. Pearson, and L. T. Warnick. 1998. Timing of insemination for dairy cows identified in estrus by a radiotelemetric estrus detection system. J. Dairy Sci. 81:1874-1882.

Durand, M., and R. Kawashima. 1980. Influence of minerals in rumen microbial digestion. Pages 375-383 in Digestive Physiology and Metabolism in Ruminants. Ruckebusch and Thivend, ed. Lancaster, England.

Eckles, C. H., T. W. Gullickson, and L. S. Palmer. 1932. Phosphorus deficiency in the rations of cattle. Univ. Minn. Agric. Exp. Stan. Bull. 91:1-118.

Fricke, P. M., and M. C. Wiltbank. 1999. Effect of milk production on the incidence of double ovulation in dairy cows. Theriogenology 52:1133-1143.

Fricke, P. M., J. N. Guenther, and M. C. Wiltbank. 1998. Efficacy of decreasing the dose of GnRH used in a protocol for synchronization of ovulation and timed AI in lactating dairy cows. Theriogenology 50:1275-1284.

Hignett, S. L., and P. G. Hignett. 1952. The influence of nutrition on reproductive efficiency in cattle. The effect of phosphorus intake on ovarian activity and fertility of heifers. Vet. Rec. 64:203-206.

Hurley, W. L., L. A. Edgerton, D. Olds, and R. W. Hemken. 1982. Estrous behavior and endocrine status of dairy heifers with varied intakes of phosphorus. J. Dairy Sci. 65:1979-1986.

Lopez, H., F. D. Kanitz, V. R. Moreira, M. C. Wiltbank, and L. D. Satter. 2004. Effect of dietary phosphorus on performance of lactating dairy cows: milk production and cow health. J. Dairy Sci. 87:139-145.

Lopez, H., Z. Wu, R. Cherel, L. D. Satter, and M. C. Wiltbank. 2001. Effect of dietary phosphorus concentration on estrous behavior of lactating dairy cows. J. Dairy Sci. 84(Suppl. 1):291. (Abstr.)

Moreira, F., O. Orlandi, C. A. Risco, R. Mattos, F. Lopes, and W. W. Thatcher. 2001. Effects of presynchronization and bovine somatotropin on pregnancy rates to a timed artificial insemination protocol in lactating dairy cows. J. Dairy Sci. 84:1646-1659.

Morrow, D. A. 1969. Phosphorus deficiency and infertility in dairy heifers. J. Am. Vet. Med. Assoc. 154:761-768.

National Research Council. 1971. Nutrient Requirements of Dairy Cattle, 3rd rev. ed. Natl. Acad. Sci., Washington, DC.

National Research Council. 2001. Nutrient Requirements of Dairy Cattle, 7th rev. ed. Natl. Acad. Sci., Washington, DC.

Noller, C. H., A. G. Castro, W. E. Wheeler, D. L. Hill, and N. J. Moeller. 1977. Effect of phosphorus supplementation on growth 
rate, blood minerals, and conception rate of dairy heifers. J. Dairy Sci. 60:1932-1940.

Palmer, L. S., T. W. Gullickson, W. L. Boyd, C. P. Fitch, and J. W. Nelson. 1941. The effect of rations deficient in phosphorus and protein on ovulation, estrous, and reproduction of dairy heifers. J. Dairy Sci. 24:199-210.

Pursley, J. R., M. O. Mee, and M. C. Wiltbank. 1995. Synchronization of ovulation in dairy cows using $\mathrm{PGF}_{2 \alpha}$ and $\mathrm{GnRH}$. Theriogenology 44:915-923.

Pursley, J. R., P. M. Fricke, H. A. Garverick, D. J. Kesler, J. S. Ottobre, J. S. Stevenson, and M. C. Wiltbank. 2001. Improved fertility in noncycling lactating dairy cows treated with exogenous progesterone during Ovsynch. J. Dairy Sci. 83(Suppl. 1):1563. (Abstr.)

Pursley, J. R., R. W. Silcox, and M. C. Wiltbank. 1998. Effect of time of artificial insemination on pregnancy rates, calving rates, pregnancy loss, and gender ratio after synchronization of ovulation in lactating dairy cows. J. Dairy Sci. 81:2139-2144.

SAS. 1996. User's guide: Statistics, Version 6 Edition. SAS Institute, Inc. Cary, N.C.

Theiler, A. H., H. Green, and P. J. Du Toit. 1928. Studies in mineral metabolism III. Breeding of cattle on phosphorus deficient pasture. J. Agr. Sci. (Camb.) 18:369-371.

Valk, H., and L. B. J. Sebek. 1999. Influence of long-term feeding of limited amounts of phosphorus on dry matter intake, milk production, and body weight of dairy cows. J. Dairy Sci. 82:2157-2163.

Vasconcelos, J. L. M., R. W. Silcox, J. A. Lacerda, J. R. Pursley, and M. C. Wiltbank. 1997. Pregnancy rates, pregnancy loss, and response to heat stress after AI at two different times from ovulation in dairy cows. Biol. Reprod. 56(Suppl. 1):140. (Abstr.)

Walker, W. L., R. L. Nebel, and M. L. McGilliard. 1996. Time of ovulation relative to mounting activity in dairy cattle. J. Dairy Sci. 79:1555-1561.

Wiltbank, M. C., P. M. Fricke, S. Sangsritavong, R. Sartori, and O. J. Ginther. 2000. Mechanisms that prevent and produce double ovulations in dairy cows. J. Dairy Sci. 83:2998-3007.

Wu, Z., and L. D. Satter. 2000. Milk production and reproductive performance of dairy cows fed two concentrations of phosphorus for two years. J. Dairy Sci. 83:1052-1063.

Wu, Z., L. D. Satter, A. J. Blohowiak, R. H. Stauffacher, and J. H. Wilson. 2001. Milk production, estimated phosphorus excretion, and bone characteristics of dairy cows fed different amounts of phosphorus for two or three years. J. Dairy Sci. 84:1738-1748.

Wu, Z., L. D. Satter, and R. Sojo. 2000. Milk production, reproductive performance, and fecal excretion of phosphorus by dairy cows fed three amounts of phosphorus. J. Dairy Sci. 83:1028-1041.

Xu, Z. Z., D. J. McKnight, R. Vishwanath, C. J. Pitt, and L. J. Burton. 1998. Estrus detection using radiotelemetry or visual observation and tail painting for dairy cows on pasture. J. Dairy Sci. 81:2890-2896 